\title{
Spermine and Spermidine, Modulators of the Cell Surface Enzyme Adenylate Cyclase
}

\author{
R. K. WRIGHT, B. A. BUEHLER, S. N. SCHOTT, AND O. M. RENNERT (299) \\ Division of Genetics, Endocrinology and Metabolism, Department of Pediatrics, University of Florida College of \\ Medicine, and University of Florida Sunland Research Laboratories, Gainesville, Florida, USA
}

\begin{abstract}
Summary
Adenylate cyclase activity was measured in membrane preparations of cultured fibroblasts from controls and patients with cystic fibrosis. Enzyme activity increased as the transition from exponential growth to confluence occurred; sodium fluoride-stimulated activity more markedly displayed this relationship than basal cyclase activity. The in vitro addition of spermine $\left(1 \times 10^{-6}\right.$ to $\left.2 \times 10^{-3} \mathrm{M}\right)$ to membrane preparations caused inhibition of basal and sodium fluoride-stimulated enzyme activity, with $50 \%$ inhibition of basal activity occurring at $10^{-6} \mathrm{M}$ spermine. Spermidine $\left(10^{-4} \mathrm{M}\right)$ caused $15-25 \%$ inhibition of adenylate cyclase activity. The increase in fibroblast adenylate cyclase activity during the transition from exponential growth was comparable in cells obtained from cystic fibrosis patients and control subjects. Basal and sodium-fluoride stimulated adenylate cyclase activity as well as inhibition of this enzyme activity by spermidine and spermine were undistinguishable between the different cell genotypes. A potential modulation of cellular proliferative activity through polyamine interaction with the adenylate cyclase system is postulated.
\end{abstract}

\section{Speculation}

Buchwald and associates (5) observed increased levels of cyclic AMP in cultured fibroblasts obtained from cystic fibrosis patients. Similarly, Mangos and collaborators (15) have suggested that altered regulation of cyclic nucleotide metabolism may be an etiologic factor in the pathophysiology of the exocrine dysfunction of cystic fibrosis. Effector molecules whose actions are mediated through changes in cyclic nucleotide metabolism induce changes in both the polyamine biosynthetic machinery and in the intracellular concentrations of these amines. These changes in polyamine metabolism occur concomitantly or precede those of cyclic nucleotide metabolism. This investigation postulates that the naturally occurring polyamines putrescine, spermidine and spermine act as second messengers and may exert their effects by modulating adenylate cyclase. Since an abnormality of polyamine metabolism occurs in cystic fibrosis, these relationships of polyamine modulation of adenylate cyclase activity were investigated in cystic fibrosis fibroblasts.

Factors which modulate adenylate cyclase are varied and complex. Recent reports indicate polycations (26), hydrogen ion (8), sodium fluoride (12), and hormones (8) have specific effects on this enzyme. Otten et al. (17), suggested that cyclic AMP levels in slow growing cells are higher than in rapidly growing cells and the addition of dibutyryl cyclic AMP is paralleled by an increase in adenylate cyclase activity (1).

Recent investigations in our laboratory (4) verified the relationship of the polyamine biosynthetic pathway to proliferation of human fibroblasts and indicated concomitant changes in ornithine decarboxylase and $S$-adenosyl methionine decarboxylase as the monolayer approached confluence. Ornithine decarboxylase and $S$-adenosyl methionine decarboxylase are key enzymes necessary for the synthesis of polyamines. Studies on the ornithine carboxylase and $S$-adenosyl methionine decarboxylase indicated that no difference existed between cystic fibrosis and control fibroblasts with regard to activity in relationship to growth cycle nor in feedback inhibition or activation (4). This investigation examines the effect of the naturally-occurring polyamines spermine and spermidine on the membrane-bound adenylate cyclase system in human fibroblasts since these cationic polyamines have been shown to be increased in cystic fibrosis $(7,20)$.

The observation of increased levels of cyclic AMP in cultured fibroblasts and in parotid preparations from cystic fibrosis patients $(5,15)$ and increased levels of blood polyamines in these individuals supported the validity of an evaluation of the interaction of polyamines and adenylate cyclase activity in this disease. Additionally, reports of altered ATPase activity in cystic fibrosis added further indirect reasons to explore the modulation of membranebound enzyme activity since the activity of both the cholinesterase and ATPase systems is modulated by polyamines (13).

\section{MATERIALS AND METHODS}

Cultured skin fibroblasts from three normal adults (aged 20-35 years), 6 normal children (aged 1 week-13 years) and six children with cystic fibrosis (2-12 years) were cultured in $75 \mathrm{~cm}^{2}$ Falcon flasks at $37^{\circ}$ in a $5 \% \mathrm{CO}_{2}$ atmosphere. This protocol was approved by the institutional human experimentation committee and informed consent was obtained for the skin biopsy. The cells were cultured in $15 \mathrm{ml}$ Eagle's minimum essential medium with $20 \%$ fetal calf serum, penicillin $100 \mu \mathrm{g} / \mathrm{ml}$, streptomycin $100 \mu \mathrm{g} / \mathrm{ml}$, fungizone $25 \mu \mathrm{g} / \mathrm{ml}$ ( $1 \%$ antibiotic-antimycotic mixture), $10 \mathrm{mM}$ Hepes buffer, and $1 \%$ nonessential amino acids with $2 \mathrm{mM} \mathrm{L-}$ glutamine. All culture materials were purchased from Gibco. Confluent flasks were trypsinized and split 1:2 or 1:324 hr before assay. At the time of assay, $2 \mathrm{ml}$ of $0.1 \mathrm{M}$ sodium phosphate buffer, $\mathrm{pH} 7.2$, was added to each flask, and the cells were removed by scraping with a rubber policeman. Cells from 20 flasks were harvested and centrifuged at $900 \times g$ for 10 minutes at $4^{\circ}$. The resulting pellet was resuspended in $5.5 \mathrm{ml} 0.1 \mathrm{M}$ sodium phosphate buffer, pH 7.2, with $5 \mathrm{mM}$ dithiothreitol and $0.05 \mathrm{mM}$ pyridoxal phosphate.

The cell suspension was frozen-thawed twice in liquid nitrogen. Next $0.1 \mathrm{ml}$ was removed for determination of the DNA content using the modified diphenylamine reaction of Richards (21). After freeze-thawing, the mixture was spun at $25,000 \times \mathrm{g}$ for $15 \mathrm{~min}$ at $4^{\circ}$ in a Beckman LD3-40 ultracentrifuge. The supernantant and pellet were separated and the pellet resuspended in $0.5-0.1 \mathrm{ml} 50$ $\mathrm{mM}$ Tris buffer, $\mathrm{pH} 7.5$, and $5 \mathrm{mM}$ magnesium. Then $0.05 \mathrm{ml}$ was removed for protein determination by the method of Lowry (14). All reactions were performed in polypropylene tubes as described by Salomon et al. (24). Fifty microliters of sample, containing $0.10-0.38 \mathrm{mg}$ protein, were incubated in $1 \mathrm{mM}$ cyclic AMP (Sigma), $0.5 \mathrm{mM}$ ATP (Sigma), $20 \mathrm{mM}$ creatine phosphate (Sigma), $100 \mu \mathrm{U} / \mathrm{ml}$ creatine phosphate kinase (Sigma), $0.1 \mathrm{mM}$ isobutylmethylxanthine (Aldrich), $2.5 \times 10^{6} \mathrm{cpm}$ of $\left[\alpha{ }^{-32} \mathrm{P}\right] \mathrm{ATP}$ 
(New England Nuclear), and $25 \mathrm{mM}$ Tris buffer, pH 7.5, with 5 $\mathrm{mM}$ magnesium. The reaction was incubated at $37^{\circ}$ for $10 \mathrm{~min}$ and then stopped with $0.10 \mathrm{ml} 2 \%$ sodium dodecylsulfate, $40 \mathrm{mM}$ ATP, and $1.5 \mathrm{mM}$ cyclic AMP. The resulting mixture was incubated at $70^{\circ}$ for $5 \mathrm{~min}$. Before separation of cyclic $\left[{ }^{32} \mathrm{P}\right] \mathrm{AMP}, 1.3$ $\times 10^{4} \mathrm{cpm}$ of cyclic $\left[{ }^{3} \mathrm{H}\right] \mathrm{AMP}$ was added and the mixture brought to a final volume of $1.05 \mathrm{ml}$ with distilled water.

Separation of cyclic $\left[{ }^{32} \mathrm{P}\right] \mathrm{AMP}$ was accomplished as described by Salomon $e t$ al. (24) Samples were applied to columns $(0.7 \times 4$ $\mathrm{cm}$ ) of Dowex AG50 W-X4; $1 \mathrm{ml} \mathrm{H}_{2} \mathrm{O}$ was eluted twice and discarded. Columns containing $0.6 \mathrm{~g}$ Alumina-neutral were prepared by washing with $10 \mathrm{ml} 0.1 \mathrm{M}$ imidazole, $\mathrm{pH} 7.5$, and then placed under the Dowex columns. Distilled water $(3 \mathrm{ml})$ was added to the Dowex columns and eluant allowed to flow into the alumina column. The alumina column was placed in a scintillation vial and washed twice with $2.5 \mathrm{ml}$ of $0.1 \mathrm{M}$ imidazole, $\mathrm{pH} 7.5$. Aquasol scintillation counting fuid (New England Nuclear), 15.0 $\mathrm{ml}$, was added to the scintillation vials and counted in a Hewlett Packard Tri-Carb scintillation spectrometer model 3320. Seventy to ninety percent of the cyclic [ $\left.{ }^{3} \mathrm{H}\right] \mathrm{AMP}$ was recovered and results have been corrected accordingly.

\section{RESULTS}

The amount of cyclic $\left[{ }^{32} \mathrm{P}\right]$ AMP formed from $\left[\alpha-{ }^{32} \mathrm{P}\right] \mathrm{ATP}$ increased linearly with time from $0-15 \mathrm{~min}$. The reaction was linear with respect to protein concentration up to $150 \mathrm{mg}$. The basal adenylate cyclase activity for all cell lines ranged from 27-34 $\mathrm{pmol} / \mathrm{mg}$ protein $10 \mathrm{~min}$. Addition of $10 \mathrm{mM}$ sodium fluoride

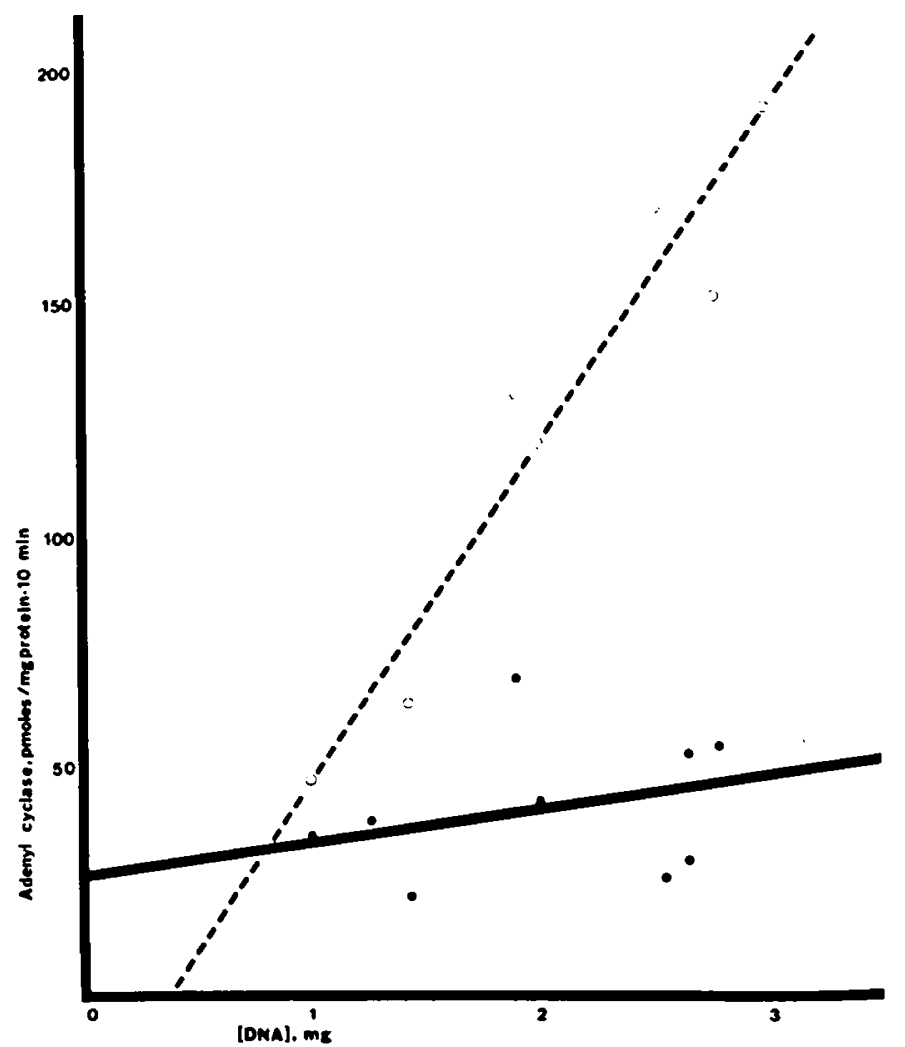

Fig. 1. Adenylate cyclase activity as a function of DNA concentration. Adenylate cyclase specific activity was assayed in duplicate as described in Materials and Methods. Each point represents a separate experiment in which the DNA content of a fixed volume was measured. The DNA concentration varied as a function of relative confluence or cell density. The solid line basal adenylate cyclase specific activity versus DNA was calculated by least squares to give a regression line with $\mathrm{y}=8.6+24.6$. The dotted line represents adenylate cyclase specific activity in the presence of $5 \mathrm{mM} \mathrm{NaF}$. caused a 2- to 4-fold rise in measured adenylate cyclase activity.

DNA measurements on cultures showed an equivalent increasing DNA content with increased cell numbers. At confluence, there were approximately $3 \times 10^{7}$ cells $/ 75 \mathrm{~cm}^{2}$ flask. The doubling time of these fibroblasts in our laboratory is approximately $24 \mathrm{hr}$; the increment in DNA concentration reflects the days postsubculture.

Levels of enzyme activity were dependent on the growth phase of the cells as reflected by DNA concentrations (see Fig. 1). Adenylate cyclase activity, $\mathrm{NaF}$-stimulated, increased as the cells approach confluence. The linear regression calculated from basal adenylate cyclase activity as a function of the transition from experimental growth towards confluence may reflect increasing specific activity as the culture approached the stationary phase. The mean adenylate cyclase activity independent of the growth phase of the cultures from control subjects and cystic fibrosis patients showed no differences (Table 1). In the absence of magnesium ions no measurable adenylate cyclase activity was observed.

The addition of spermine to cell membrane preparations inhibited adenylate cyclase activity (Fig. 2). Fifty percent inhibition of basal enzyme activity occurred at $10^{-6} \mathrm{M}$ spermine, and maximal inhibition was approached at $10^{-4} \mathrm{M}$ spermine (Fig. 3). Spermine inhibited basal adenylate cyclase activity as well as NaF-stimulated enzyme activity. The enzyme inhibition displayed saturation kinetics. No further significant inhibition of adenylate cyclase activity occurred at spermine concentrations greater than $10^{-4} \mathrm{M}$.

$\left[\mathrm{F}^{-}\right]$stimulation of adenylate cyclase resulted in a 5-fold increase in activity (Table 2 ). An equivalent inhibition of $\mathrm{NaF}$-stimulated adenylate cyclase was observed with equimolar concentrations of spermine and spermidine (Table 2 ). Basal adenylate cyclase activity was inhibited only $15 \%$ by spermidine as contrasted to $35 \%$ by spermine (Tables 1 and 2). Preincubation of membrane preparations also resulted in inhibition of cyclase activity.

Preliminary studies with putrescine, $10^{-4} \mathrm{M}$, indicated inhibition of adenylate cyclase activity, but to a lesser extent than equimolar concentrations of spermine. Arginine and ornithine demonstrated no inhibitory effects at $10^{-4} \mathrm{M}$. Diaminopropane and agmatine had no effect.

No differences in basal, NaF-stimulated, or spermine inhibition of adenylate cyclase activity were observed between control fibroblasts and cells from patients with cystic fibrosis.

\section{DISCUSSION}

Kossorotow et al. (13) and Rosenthal and Buchanan (22) have shown that spermine and spermidine are capable of modulating the activity of membrane-bound $\left(\mathrm{Na}^{+} / \mathrm{K}^{+}\right)$-ATPase and acetyl cholinesterase. Previous experiments in our laboratories $(3,6)$ offered evidence for a cell surface action of these organic cations; Chun et al. (6) have shown the binding of polyamines to the erythrocyte membrane and demonstrated alterations in the electrokinetic properties of these cells as a consequence of this interaction. These observations and those of other groups $(15,25,26)$

Table 1. Adenylate cyclase assay for production of cyclic $l^{32} P J A M P^{1}$

\begin{tabular}{lcccccccc}
\hline & \multicolumn{3}{c}{$\begin{array}{c}\text { Adenylate cyclase, no } \\
\text { additions }\end{array}$} & & \multicolumn{2}{c}{$\begin{array}{c}\text { Adenylate cyclase }+10^{-4} \\
\text { M spermine }\end{array}$} \\
\cline { 2 - 3 } \cline { 7 - 9 } \multicolumn{1}{c}{ Cell line } & $\bar{\chi}$ sp act & SE & $n$ & $\bar{\chi}$ sp act & $n$ & $\begin{array}{c}\text { \% inhibi- } \\
\text { tion }\end{array}$ \\
\hline Normal children & 31.9 & 5.9 & 20 & & 17.0 & 14 & 34.5 \\
Normal adults & 30.2 & 6.9 & 9 & & 18.5 & 7 & 33.0 \\
CF patients & 32.7 & 6.0 & 14 & 24.5 & 10 & 32.0 \\
\hline
\end{tabular}

'Adenylate cyclase was assayed for the production of cyclic [ $\left.{ }^{32} \mathrm{P}\right] \mathrm{AMP}$ in duplicate as described under Materials and Methods. Specific activity units are picomoles per $\mathrm{mg}$ protein for $10 \mathrm{~min}, \bar{x}$ is the mean value, $n$ is the number of experiments. 
prompted our examination of the influence of polyamines on adenylate cyclase.

The polyamines spermine and spermidine directly inhibit adenylate cyclase activity at physiologic concentrations (Fig. 3, Table

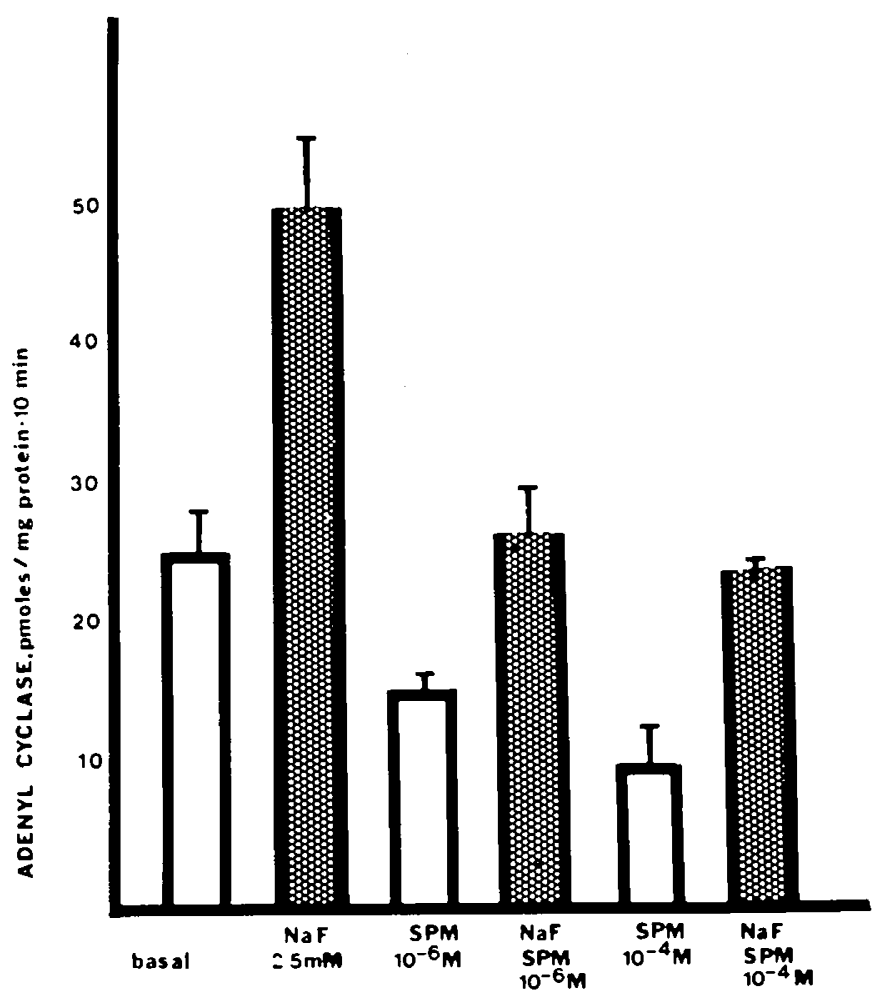

Fig. 2. Inhibition of basal and fluoride-stimulated adenylate cyclase activity by spermine. Adenylate cyclase specific activity was measured as described in Materials and Methods with $2.5 \mathrm{mM} \mathrm{NaF}$ and/or spermine concentration as shown. Values represent the average of two incubations. Activity was assayed wtith $0.16 \mathrm{mg}$ cell membrane protein from $1.2 \times 10^{6}$ normal fibroblasts (cell line established in this laboratory from infant foreskin).
2). Recent work suggests that the $\mathrm{NaF}$-sensitive adenylate cyclase is minimally dependent upon $\mathrm{Ca}^{++}$concentration and is different from the cation-dependent portion (10); spermidine and spermine may inhibit both of these activities (Fig. 3, Table 2).

$\mathrm{NaF}$-stimulated adenylate cyclase activity increased as cultures became confluent (Fig. 1). This is compatible with the increased intracellular cyclic AMP levels in WI38 cultured cells reported by O'Neill and Hsie (16). Buehler et al. (4) indicated that ornithine decarboxylase activity was maximal during exponential growth. Data from several sources suggests that endogenous polyamine levels are increased during increased proliferative activity. Raina and Janne (19) reported that the concentration of spermidine is highest in young animals and decreases with aging, whereas spermine changes less, but in a parallel fashion. Additionally, the increased synthesis and accumulation of polyamines with rapid growth of animal tissue is documented specifically in situations such as liver regeneration and cellular regeneration following tissue loss $(9,11,23)$. Preliminary work in our laboratory indicates that intracellular levels of polyamines are increased during exponential growth in human fibroblast cultures. The data in this report indicate that exogenous polyamines are capable of inhibiting the in vitro activity of adenylate cyclase of human fibroblast membrane preparations. It remains to be demonstrated whether variations of intracellular polyamine levels function in a similar role in vivo. A potential role of polyamines as modulators of cell membrane function is therefore postulated.

The suggestions of altered cyclic nucleotides concentrations in cystic fibrosis tissue $(5,15)$ and the demonstration of increased

Table 2. Effect of spermine and spermidine on adenylate cyclase

\begin{tabular}{lcrc}
\hline Incubation conditions & $\begin{array}{c}\text { Adenylate cyclase activ- } \\
\text { ity, pmol/mg protein } \cdot 10 \\
\text { min }\end{array}$ & $n$ & $\begin{array}{c}\% \\
\text { Inhibition }\end{array}$ \\
\hline Basal & $31.9 \pm 5.9$ & 20 & \\
$10^{-4} \mathrm{M}$ spermidine $_{2 \times 10^{-2} \mathrm{M} \mathrm{F}^{-}}$ & 27.2 & 6 & 15 \\
$\mathrm{~F}^{-}+$spermine $\left(10^{-4} \mathrm{M}\right)$ & $162.9 \pm 13.4$ & 22 & \\
$\mathrm{~F}^{-}+$spermidine $\left(10^{-4} \mathrm{M}\right)$ & 127.4 & 14 & 22 \\
\hline
\end{tabular}

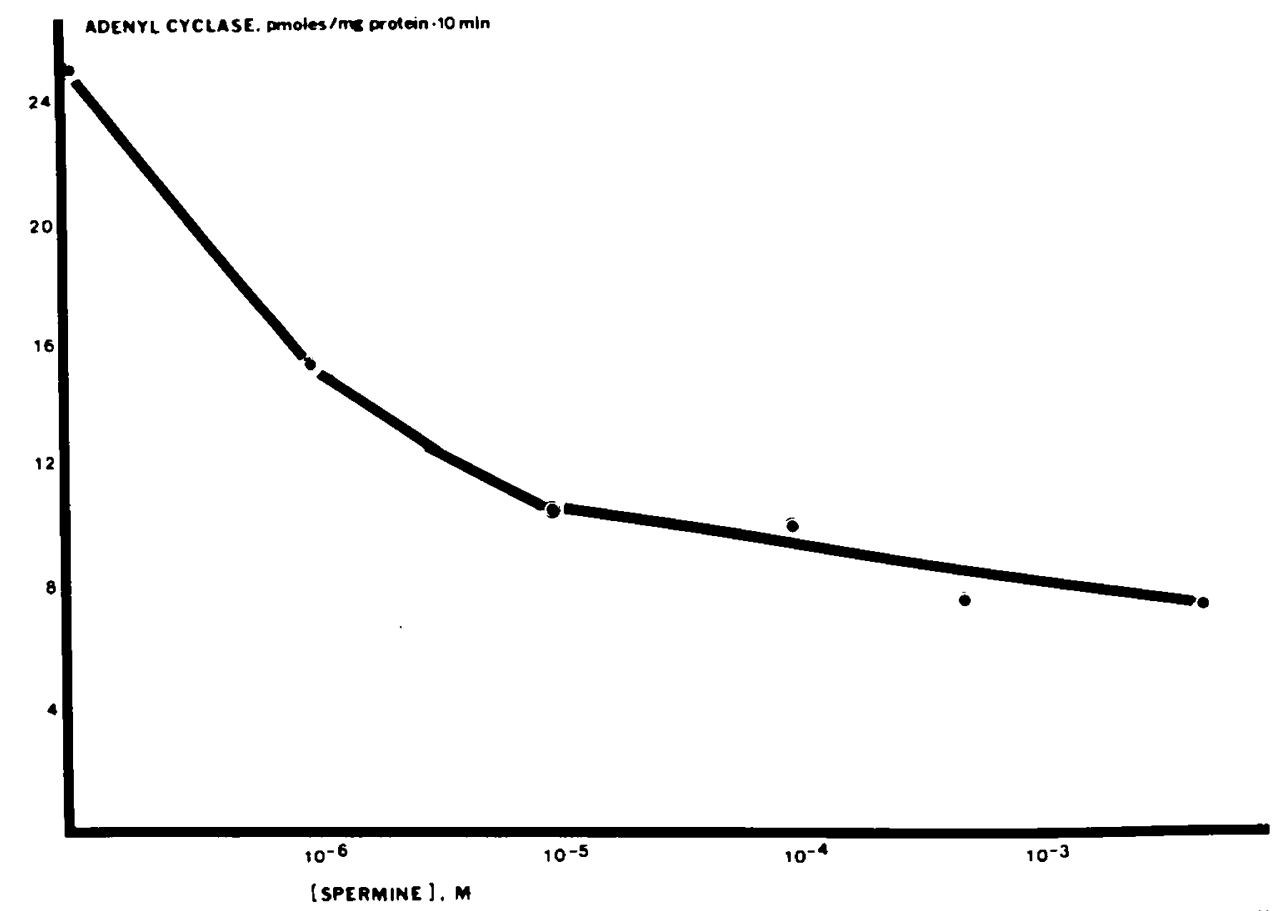

Fig. 3. Adenylate cyclase specific activity as a function of spermine concentration. Adenylate cyclase was assayed in duplication for 10 min in the presence of varying concentrations of spermine. Each assay contained $0.16 \mathrm{mg}$ cell membrane protein from $1.2 \times 10^{6}$ normal fibroblasts. Production of cyclic $\left[{ }^{32}\right.$ P]AMP was determined as described in Materials and Methods. 
blood polyamines in cystic fibrosis $(7,15,21)$ made it reasonable to seek a dysfunction in the interaction of these two systems. The data presented indicate normal adenylate cyclase activity which is inhibited by polyamines to the same extent as is the enzyme from control fibroblasts.

\section{CONCLUSION}

These studies document changes in cultured fibroblast adenylate cyclase as these cells transit from exponential growth to the stationary phase. In vitro data is presented to show that spermine is an inhibitor of adenylate cyclase, that spermidine is a less efficient inhibitor of this enzyme and that putrescine has a minimal effect. The concentrations of spermine and spermidine which inhibit adenylate cyclase are comparable to those observed in in vivo cultured cells. No differences in the adenylate cyclase of normal and cystic fibrosis fibroblasts were noted.

\section{REFERENCES AND NOTES}

1. Anderson, W. B., and Pastan, I.: Cyclic nucleotides and the contraction of smooth muscle. Advan. Cyclic Nucl. Res., 5: 681 (1975).

2. Amatruda, J., and Lockwood, D.: Studies of the insulin-like action of polyamines in adipose tissue cells. Biochem. Biophys. Acta. 373: 266 (1974).

3. Arvanitakis. S., McSherry, N., Mangos, J., LaPointe, D., and Rennert, O.: Cystic fibrosis and polyamine metabolism. Tex. Rep. Biol. Med., 34: 175 (1976).

4. Buehler, B., Wright. R., Schott. S., Darby. B., and Rennert, O.: Ornithine decarboxylase and $S$-adenosyl methionine decarboxylase in skin fibroblasts of normal and cystic fibrosis patients. Pediat. Res. $/ 1$ : 186 (1977).

5. Buchwald. M.: Abnormal levels of 3',5'-cyclic AMP in isoproterenol-stimulated fibroblasts from patients with cystic fibrosis. Proc Nat Acad. Sci. U. S. A., 73: 2899 (1976).

6. Chun, P., Rennert, O., Saffen, E., and Taylor, J.: Efrect of polyamines on the electrokinetic properties of red blood cells. Biochem Biophys. Res. Commun., 69: 1095 (1976).

7. Cohen, L., Farrell, P., Willison, J.. Lundgren. D.: Localization of spermidine and spermine in blood of cystic fibrosis and control subjects. Pediat. Res., 9: 334 (1975).

8. Cuetracasas, P.: Receptors and cyclic nucleotides. Advan. Cyclic Nucl. Res., 5: 79 (1975).

9. Dykstra, W., and Herbst, E.: Spermidine in regenerating liver in relation to rapid synthesis of RNA. Science, 149: 428 (1965).

10. Franks, D., Perrin, L., and Malamud. D.: Calcium ion: A modulator of parotid adenylate cyclase activity. FEBS Lett. 42: 267 (1974).

11. Holtta, E., Sinerrirta, R., and Janne, J.: Synthesis and accumulation of polyamines in rat liver regenerating after treatment with carbon tetrachloride. Biochem. Biophys. Res. Commun.. 54: 350 (1973).

12. Johnson, R., Pilkis, S., and Hamet. P.: Liver membrane adenylate cyclase. J. Biol. Chem., 250: 6599 (1975).

13. Kossorotow, A., Wolf, H.., and Seiler, N.: Regulatory effects on membrane bound acetyl cholinesterase. Biochem. J. 144: 21 (1974).

14. Lowry, O. H., Rosebrough. N. J., Farr; A. L., and Randall, R. J.: Protein measurement with the Falin phenol reagent. J. Biol. Chem.. 193: 265 (1951).

15. Mangos, J., Bargman, G., Martinez, R., and Rennert. O.: Physiology and pharmacology of secretion and cystic fibrosis. J. A. Mangos and R. Talamo. In Cystic Fibrosis Projections into the Future, pp. 311-336 (New York and London, Intercontinental Medical Book Corp., 1976).

16. O'Neill, J., and Hsie. A.: PGE. effects on CAMP levels and the relationship to fibroblast density in culture. Biochim. Biophys. Acta, 404: 243 (1975)

17. Otten. J.. Johnson, G., and Pastan. I.: Regulation of cell growth by cyclic AMP. J. Biol. Chem., 247: 7082 (1972).

18. Proctor, M., Fletcher, V., Shukla, J., and Rennert. O.: Elevated spermidine and spermine levels in the blood of psoriasis patients. J. Invest. Dermatol.. 65: 409 (1975).

19. Raina, A., and Janne, J.: Physiology of the natural polyamines putrescine. spermidine and spermine. Med. Biol., 53: 121 (1975).

20. Rennert, O., Frias, J., and Shukla, J: Polyamine metabolism in cystic fibrosis. Tex. Rep. Biol. Med.. 34: 187 (1976).

21. Richards, G.: Modifications of the diphenylamine reaction giving increased sensitivity and simplicity in the extimation of DNA. Anal. Biochem.. 57: 369 (1974).

22. Rosenthal. S., and Buchanan. A.: Influences of cationic bactericidal agents on membrane ATPase of Bacillus subtilis. Biochim. Biophys. Acta. 363: 141 (1974).

23. Russell, D., and Synder, S.: Amine synthesis in rapidly growing tissues: ODA activity in regenerating rat liver. Proc. Natl. Acad. Sci. U. S. A., 60: 1420 (1968).

24. Salomon, Y., Loudos, C.. and Rodbell, M.: A highly sensitive adenylate cyclase assay. Anal. Biochem., 58: 541 (1974).

25. Tashima, $Y_{\text {, }}$ and Hasegawa, M.: Specific inhibition of ouabain sensitive and $K^{+}$. dependent $p$-hitrophenylphosphatase by polyamines. Biochem. Biophys. Res. Commun., 66: 1344 (1975).

26. Wolff, J., and Cook. G. H.: Charge effects in the activation of adenylate cyclase. J. Biol. Chem., 250: 6897 (1975).

27. Wright, R. K., Mandy. S. H., Halprin, K., and Hsia. S. L.: Defects and deficiency of adenyl cyclase in psoriatic skin. Arch. Dermatol., 107: 47 (1973).

28. This research was supported by NIH Training Grant AM05680-04 and research grants from the Cystic Fibrosis Foundation. the Boehringer Mannheim Corporation and the Hayward Foundation.

29. Requests for reprints should be addressed to: Dr. O. M. Rennert, Department of Pediatrics, University of Oklahoma Health Sciences Center. PO Box 26901. Oklahoma City, OK 73190 (USA).

30. Received for publication June 9. 1977

31. Accepted for publication October 18, 1977. 